\title{
Increasing Interest in Learning in the Pandemic Era with Online Learning Using Powerpoint and Googlemeet Media
}

\section{Dwi Susanti}

SD Negeri Raci 02

dwisusanti067@gmail.com

\section{Article History}

received 3/12/2020

revised 17/12/2020

accepted 31/12/2020

\begin{abstract}
The purpose of this study is to find out how students' interest in learning in online learning uses powerpoint and google meet media, supporting and inhibiting factors in online learning using powerpoint and google meet media in class III SD Negeri Raci 02 Batangan District, Pati Regency. This research is a qualitative research with descriptive analysis technique. Analysis of research data obtained from the process of searching and compiling systematically, data obtained from observations and interviews, namely data collection, data processing, data presentation, and conclusions. The results showed that interest in learning in the pandemic era with online learning using powerpoint and googlemeet media in class III experienced a good increase. The use of interesting new media fosters a new enthusiasm for students in participating in online learning. Inhibiting factors are time efficiency and effectiveness, lack of parental assistance. Supporting factors are, schools facilitate teachers in schools, and students are given free internet quota.
\end{abstract}

Keywords: interest in learning, power point media, googlemeet

\begin{abstract}
Abstrak
Tujuan penelitian ini yaitu untuk mengetahui bagaimana minat belajar peserta didik pada pembelajaran daring menggunakan media powerpoint dan google meet, factor pemdukung dan penghambat dalam pembelajaran daring menggunakan media powerpoint dan google meet di kelas III SD Negeri Raci 02 Kecamatan Batangan Kabupaten Pati. Penelitian ini merupakan penelitian kualitatif dengan teknik analisis deskriptif. Analisis data hasil penelitian diperoleh dari proses mencari dan menyusun secara sistematis, data yang diperoleh dari hasil observasi dan wawancara yaitu pengumpulan data, pengolahan data, penyajian data, dan simpulan. Hasil penelitian menunjukkan bahwa minat belajar di era pandemi dengan pembelajaran daring menggunakan media powerpoint dan googlemeet di kelas III mengalami peningkatan yang baik. Penggunaan media baru yang menarik menumbuhkan semangat baru peserta didik dalam mengikuti pembelajaran daring. Faktor penghambat yaitu efisiensi dan efektifitas waktu, kurangnya peran pendampingan orang tua. Faktor pendukung yaitu, sekolah memfasilitasi guru di sekolah, dan peserta didik diberikan kuota internet gratis.
\end{abstract}

Kata kunci: minat belajar, media power point, googlemeet

Social, Humanities, and Education Studies (SHEs): Conference Series https://jurnal.uns.ac.id/shes

p-ISSN 2620-9284 e-ISSN 2620-9292 


\section{PENDAHULUAN}

Pada awal tahun 2020 dunia digemparkan dengan adanya virus yang melanda berbagai negara yaitu berjumlah 215 negara. Virus tersebut dikenal dengan istilah Covid-19. Untuk mengatasi penyebaran virus ini, pada tanggal 24 Maret 2020, Mendikbud RI mengeluarkan surat edaran Nomor 4 Tahun 2020 tentang Kebijakan Pendidikan dalam masa Darurat Penyebaran Covid-19. Surat edaran tersebut menegaskan bahwa proses pembelajaran harus dilaksanakan secara daring atau jarak jauh. Pembelajaran daring diharapkan mampu memutus rantai penyebaran Covid-19. Pembelajaran daring memungkinkan peserta didik memiliki keleluasaan karena dapat belajar kapan pun dan dimana pun. Pembelajaran daring merupakan pembelajaran yang membutuhkan koneksi internet dalam penggunaannya. Namun, pembelajaran daring tidak sepenuhnya berjalan dengan efektif. Permasalahan yang banyak ditemui saat pembelajaran daring adalah keterbatasan signal dan tidak ada ketersediaan media yang mendukung. Penguasaan teknologi informasi peserta didik dan orang tua yang masih kurang menyebabkan pembelajaran daring yang dilakukan menjadi kurang efektif. Penyusunan materi, media, strategi, pendekatan, dan metode pembelajaran menjadi indicator penentu tercapainya tujuan pembelajaran yang diharapkan. Dalam pembelajaran daring saat ini peserta didik dapat berinteraksi dengan guru dan teman melalui berbagai media online seperti Google Meet. Aplikasi ini merupakan salah satu produk yang memiliki banyak kelebihan. Aplikasi ini tidak memerlukan akses internet yang tinggi sehingga mudah digunakan dimana dan kapan saja. Selain itu, aplikasi ini menyediakan vitur panggilan video yang dapat dilakukan maksimal 250 orang aktif. Penggunaan Google Meet sebagai media pembelajaran pernah digunakan dalam penelitian sebelumnya oleh Acep Roni Hamdani dengan judul penelitian "Efektifitas Implementasi Google Meet sebagai Media Pembelajaran Daring di Masa Pandemi pada Jenjang Sekolah Dasar di Kabupaten Subang", Farah Heniati Santoso dengan judul penelitian "Efektifitas Pembelajaran Google Meet Terhadap Hasil Belajar Siswa", dan Walinda dengan judul "Efektifitas Penggunaan Google Meet sebagai Media Pembelajaran". Dalam penelitian tersebut, penggunaan Google Meet dapat digunakan secara efektif dan dapat membantu dalam meningkatkan minat dan hasil belajar peserta didik. Dalam penelitian ini peneliti memanfaatkab berbagai fitur yang ada ada Google Meet seperti share screen dan white board. Dari hasil wawancara yang dilakukan guru sebagai peneliti dengan peserta didik kelas III SD Negeri Raci 02 yaitu Zahrotus Syifa selama proses pembelajaran daring belum menggunakan media online secara maksimal. Media yang digunakan hanya berupa WhatsApp. Hal tersebut sangat berpengaruh terhadap minat belajar siswa. Hasil observasi menunjukkan bahwa lebih dari $50 \%$ peserta didik belum disiplin mengirimkan tugas dan masih memiliki minat belajar yang rendah. Minat belajar yang kurang tersebut diperoleh dari hasil observasi dalam pembelajaran di Tema 1 "Pertumbuhan dan Perkembangan Makhluk Hidup", Subtema 1 "Ciri-ciri Makhluk HIdup". Oleh karena itu, latar belakang masalah tersebut, peneliti perllu melakukan inovasi media pembelajaran daring yang lebih bervariasi dengan menggunakan Google Meet. Dalam penelitian ini peneliti menggunakan berbagai vitur yang ada di Google Meet pada saat pembelajaran daring dengan judul peneliltian Peningkatan Minat Belajar di Era Pandemi dengan Pembelajaran Daring Menggunakan Media Powerpoint dan Googlemeet Peserta Didik Kelas III SD N Raci 02 Kecamatan Batangan Kabupaten Pati.

\section{METODE}

Penelitian yang dilaksanakan pada peserta didik kelas III di SD N Raci 02 Kecamatan Batangan Kabupaten Pati terkait dengan peningkatan minat belajar peserta didik pada pembelajaran daring menggunakan media powerpoint dan googlemeet adalah dengan metode kualitatif. Analisis data pada penelitian ini adalah analisis deskriptif kualitatif dimana penelitian ini menyajikan hasil berupa deskripsi 
peningkatan minat belajar pada peserta didik kelas III SD N Raci 02 Kecamatan Batangan Kabupaten Pati selama dua siklus secara daring menggunakan aplikasi Google Meet dan media powerpoint dengan dua kali pertemuan disetiap siklusnya. Siklus I dilaksanakan pada tanggal 11 dan 12 November 2019. Siklus II dilaksanakan pada tanggal 27 dan 28 November 2019. Teknik pengumpulan data yang dilakukan dengan angket dan observasi sikap, antusias, partisipasi peserta didik atas keterlaksanaan pembelajaran menggunakan media powerpoint dan googlemeet.

\section{HASIL DAN PEMBAHASAN}

Implementesi kegiatan pembelajaran daring menggunakan google meet dilaksanakan pada hari Senin tanggal 12 November 2019 sampai hari Selasa tanggal 13 November 2019. Penelitian dilakukan pada peserta didik di kelas III SD N Raci 02 Kecamatan Batangan Kabupaten Pati yang berjumlah 30 anak. Pembelajaran dilakukan dengan menggunakan berbagai fitur yang ada di google meet. Sebelum pembelajaran dimulai peserta didik dan guru bergabung dalam link google meet yang sudah dibuat oleh guru. Guru melakukan presensi untuk memastikan semua peserta didik mengikuti pembelajaran daring menggunakan fitur chat di google meet untuk menuliskan nama peserta didik yang hadir. Dengan memanfaatkan google meet, pembelajaran dapat berjalan efektif dan efisien. Guru dapat memanfaatkan berbagai fitur yang ada di google meet. Dalam pembelajaran yang berlangsung guru menjelaskan materu dengan bantuan fitur share screen yang ada di google meet. Guru membagikan materi berupa powerpoint tterkait materi yang akan disampaikan. Peserta didik sangat antusias dalam mengikuti pembelajaran dengan menggunakan google meet. Peserta didik diberikan kesempatan untuk menyampaikan gagasan, pendapat, maupun pertanyaan terkait materi yang elum dipahami secara langsung maupun dengan menggunakan fitur papan tulis yang ada di google meet. Penggunaan aplikasi tersebut dapat membantu peserta didik dalam berinterakasi dengan guru dan peserta didik yang lainnya. Dengan penggunaan google meet guru juga dapat melakukan evaluasi sikap seperti pada saat peserta didik menyampaikan pendapat, gagasan maupun menanyakan materi yang belum dipahami. Implementasi penggunaan google meet tidak sepenuhnya berjalan dengan baik. Ada beberapa kendala yang dialami peserta didik, salah satunya adalah keterbatasan signal dan kuota internet saat pembelajaran berlangsung. Ada juga kendala dari beberapa siswa yang belum bisa mengoperasikan google meet dengan baik. Pembelajaran dikatakan berjalan dengan lancar apabila peserta didik antusias mengikuti pembelajaran dan dapat menerima materi secara utuh. Peserta didik juga dapat menyampaikan gagasan dan pertanyaan terkait materi yang disampaikan oleh guru. Penggunaan media google meet dapat membantu meningkatkan antusias dan semangat peserta didik untuk mengikuti pembelajaran daring.

Kegiatan pembelajaran diawali dengan kegiatan pra siklus, kemudian dilanjutkan dengan pembelajaran siklus I dan siklus II. Hasil penelitian pada pra siklus, minat beajar peserta didik masih kurang dalam mengikuti pembelajaran daring karena guru hanya menggunakan WAG sebagai alat komunikasi pembelajaran sehingga pembelajaran kurang menyenangkan dan peserta didik lebih banyak tidak segera mengumpulkan tugas atau bahkan acuh dengan pembelajaran yang dilakukan guru. jumlah peserta didik yang disiplin mengumpulkan tugas dan aktif di WAG hanya 10 anak atau 33\% dari jumlah peserta didik kelas III yaitu 30 anak. Setelah dilakukan perbaikan dengan menerapkan pembelajaran menggunakan google meet pada siklus I, terjadi peningkatan jumlah peserta didik yang mengikuti pembelajaran dan aktif dalam pembelajaran sebanyak 18 anak atau $60 \%$ dari jumlah kelas. 
Tabel 1. Minat Belajar Peserta Didik pada PraSiklus dan Siklus I

\begin{tabular}{clcc}
\hline No. & Kegiatan Pembelajaran & $\begin{array}{c}\text { Peserta Didik } \\
\text { Hadir }\end{array}$ & $\begin{array}{c}\text { Peserta Didik } \\
\text { Tidak Hadir }\end{array}$ \\
\hline $\mathbf{1}$ & Pra Siklus & $10(33 \%)$ & $20(67 \%)$ \\
$\mathbf{2}$ & Siklus I & $18(60 \%)$ & $22(40 \%)$ \\
\hline
\end{tabular}

Berdasarkan tabel di atas dapat dijelaskan bahwa proses pembelajaran belum berhasil karena masih banyak peserta didik yang belum mengikuti pembelajaran yaitu $34 \%$ atau 18 anak, sedangkan proses pembelajaran dianggap berhasil apabila tingkat ketuntasan paling tidak mencapai $75 \%$. Dalam pembelajaran Siklus I, peneliti menggunakan google meet dan powerpoint sehingga berhasil meningkatkan minat belajar peserta didik. Hanya saja peserta didik belum terbiasa dan masih agak kesulitan beradaptasi menggunakan google meet dan powerpoint. Untuk itu harus diadakan perbaikan pembelajaran siklus II dimana peneliti akan tetap menggunakan google meet dan powerpoint diimbangi dengan latihan memanfaatkan gawai dengan maksimal. Pada siklus II penguatan pada minat belajar dan antusias peserta didik mengikuti pembelajaran semakin meningkat, karena peserta didik yang belum mengikuti pembelajaran tertarik mengikuti pembelajaran dengan cara yang baru. Setelah diadakan penelitian pada siklus II menunjukkan minat peserta didik mengkitui pembelajaran mengalami peningkatan dari siklus I. Hasil peningkatan minat belajar peserta didik dalam perbaikan pembelajaran siklus II dapat dijelaskan sebagai berikut. Jumlah peserta didik yang hadir dalam pembelajaran yaitu 27 anak atau $90 \%$ dan peserta didik yang tidak hadir yaitu 3 anak atau $10 \%$.

Tabel 2. Minat Belajar Peserta Didik pada Pra Siklus, Siklus I dan Siklus II

\begin{tabular}{clcc}
\hline No. & Kegiatan Pembelajaran & $\begin{array}{c}\text { Peserta Didik } \\
\text { Hadir }\end{array}$ & $\begin{array}{c}\text { Peserta Didik } \\
\text { Tidak Hadir }\end{array}$ \\
\hline $\mathbf{1}$ & Pra Siklus & $10(33 \%)$ & $20(67 \%)$ \\
$\mathbf{2}$ & Siklus I & $18(60 \%)$ & $22(40 \%)$ \\
$\mathbf{3}$ & Siklus II & $27(90 \%)$ & $3(10 \%)$ \\
\hline
\end{tabular}

Berdasarkan uraian di atas dapat disimpulkan bahwa proses pembelajaran siklus II telah berhasil karena tingkat minat belajar sebesar $90 \%$ dimana proses pembelajaran dianggap berhasil apabila tingkat ketuntasan paling tidak mencapai $75 \%$. Pembelajaran yang menggunakan google meet dan powerpoint berhasil meningkatkan minat belajar peserta didik. Dalam perbaikan pembelajaran siklus II jumlah peserta didik yang tertarik mengikuti pembelajaran semakin bertambah. Diperkuat dengan pengunaan berbagai fitur dalam google meet semakin meningkatkan minat dan semangat belajar peserta didik. Perbaikan pembelajaran di siklus II dianggap berhasil walau masih ada 3 peserta yang belum mengikuti pembelajaran dikarenakan orang tua sedang bekerja ketika diadakan pembelajaran. Jadi tidak perlu ada perbaikan pembelajaran selanjutnya. Untuk menindaklanjuti peserta didik yang belum dapat mengikuti pembelajaran, guru akan berkomunikasi dengan orang tua peserta didik.

Hasil dari penelitian dan observasi dari setiap siklus menunjukkan bahwa penggunaan google meet dan powerpoint terbukti dapat meningkatkan minat belajar peserta didik pada pembelajaran di kelas III SD N Raci 02 Kecamatan Batangan Kabupaten Pati. 


\section{SIMPULAN}

Berdasarkan penelitian yang sudah dilakukan oleh peneliti dengan menggunakan penelitian deskriptif kualitatif. Implementasi penggunaan google meet terhadap peningkatan minat belajar peserta didik dapat dilihat selama proses pembelajaran berlangsung. Penggunaan berbagai fitur yang ada di google meet dapat membantu guru dalam menyampaikan materi pembelajaran. Fitur yang digunakan yaitu sharescreen untuk membagikan materi di layar, white board yang dapat digunakan untuk memperjelas saat guru memberikan penjelasan berupa tulisan, dan kolom chat yang dapat digunakan peserta didik untuk menuliskan pertanyaan maupun gagasan yang belum dipahami terkait materi yang disampaikan. Selain itu google meet juga digunakan untuk proses evaluasi sikap peserta didik, seperti pada saat peserta didik menyampaikan gagasan, pikiran, pendapat, maupun pertanyaan terkait materi yang disampaikan oleh guru. Dengan demikian antusias peserta didik dapat terlihat. Guru juga dapat dengan mudah untuk menilai keaktifan peserta didik selama proses pembelajaran daring berlangsung. Implikasi yang didapatkan dari penelitian ini adanya efektifitas penggunaan Google Meet dengan minat belajar peserta didik, dilihat dari antusias keaktifan, dan sikap peserta didik selama pembelajaran berlangsung. Maka google meet dapat dijadikan media pembelajaran yang interaktif dalam pembelajaran daring. Media tersebut dapat dimanfaatkan dengan maksimal untuk peningkatan proses dan hasil belajar peserta didik.

\section{DAFTAR PUSTAKA}

Anonim. (2019). "Google Meet”. http://id.wikipedia.org/wiki/Google_Meet diakses pada tanggal 30 Desember 2019 pukul 10.41

Darmawan, Yuda. (2019). "Penggunaan Aplikasi Google Meet dalam Upaya Meningkatkan Hasil Belajar Matematika." (Surakarta: Universitas Muhammadiyah Surakarta)

Effendi, Albert. (2019). "Konsep Pembelajaran Daring Berbasis Pendekatan IImiah". Jawa Tengah: CV Sarnu Untung

Eko, Meiyanto. (2012). “Jenis-jenis Pembelajaran Jarak Jauh Berbasis Teknologi". Jurnal Telematika. Vol. 9. No. 1. (hal. 33)

Fitri, Mustika. (2019). "Efektifitas Pembelajaran Daring Berbasis Media Sosial dalam Meningkatkan Hasil Belajar", Journal of Science and Sosial Research. Vol. 3. No. 1, (hlm. 75)

Fitriyani, Yani. Irfan Fauzi. (2019). "Motivasi Belajar Mahasiswa Pada Pembelajaran Daring Selama Pandemi Covid-19". Jurnal Kependidikan. Vol. 6. No. 2 (hlm. 167)

Fuzan. Fatkhul Arifin. (2019). "The Effectiveness of Google Meet Media on The Students Learning Out of Madrasah Ibtidaiyah Teacher Education Department". Jurnal Pendidikan Guru MI. Vol. 6. No. 2 (hlm. 272)

Sawitri, Dara. (2019. "Penggunaan Google Meet untuk Work From Home di Era Pandemi Coranavirus Disease 2019 (Covid-19)". Jurnal Prioritas: Jurnal Pengabdian Masyarakat. Vol. 2. No. 1. (h/m. 56) 